\title{
IT-strategi - en didaktisk udfordring
}

\section{Lillan Madsen}

Studielektor

Institut for Idræt, Københavns Universitet

lmadsen@ifi.ku.dk

http://www.ifi.ku.dk

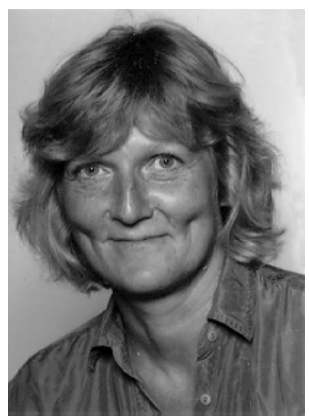

Siden år 2000 har jeg arbejdet intensivt med at udvikle nye studie- og læreprocesser i den praktisk-teoretiske undervisning, specielt i svømning på grunduddannelsen i Idrcet på Københavns Universitet (KU). Undervejs i forløbet har jeg haft stor støtte og inspiration fra samarbejdet med det Naturvidenskabelige IT Kompetence Center (NIK), Center for Naturfagenes Didaktik (CND), begge på KU, samt det eksterne samarbejde med International Multimedie Company (IMC Copenhagen, http://www.imc-copenhagen.com, som stadig er med $i$ udviklingen af strukturer og konkret praksis i relation til håndtering af de enorme mongder af videoklip).

Denne artikel følger tre spor:

- et pædagogisk-didaktisk spor, hvor den studerendes læreproces er i fokus,

- $\quad$ et T-P spor, hvor udvikling af teoretisk-praktisk sammenhæng/syntese i ny blokstruktur vægtes højt,

- et video-IT spor, for at synliggøre udvikling af en IKT-støttet studieproces der stiller krav til intens brug af IT og video.

På de følgende sider beskrives nogle af de foreløbige erfaringer med området. Artiklen gengiver kort eksempler på opgaver og studieudbytte fra de første fem blokke af uddannelsen, fra studieteknik og vandbasis i Blok 1 til eksamen online i Blok 5.

\section{Nogle grundlæggende spørgsmål}

Er det muligt i dette specielle miljø (vådt, koldt, støjende lille rum)

- at fremme lysten til analyse,

- at opsøge viden,

- at få en bedre kobling af praktik og teori,

- at diskutere med hinanden og udvikle en mere nuanceret sproglig kompetence, der forbinder det kinæstetiske, det visuelle og det fagligt teoretiske.

\section{Hvordan motiveres studerende i faget svømning til at studere?}

Idrætsstuderende og friluftsvejledere skal kvalificere sig til at udvikle og lede aktiviteter i og på vand med forskellige målgrupper. Også på åbent vand og en stor del af året. Dette stiller krav om at opnå ”konkrete færdigheder” i vand, herunder at opnå viden om og erfaring med 
egen og andres relation til ophold i vand under vekslende forhold. At give et godt råd, at fremtræde roligt og velovervejet er en vigtig færdighed, når der skal vælges rigtigt i komplekse situationer. Men hvordan tilrettelægges så en studieproces, der fører til de ønskede færdigheder, viden og erfaring?

En ny studiestruktur har skabt rammer med fire blokke, hver med to moduler, på et studieår. Det ene modul i en blok fremtræder med enten naturvidenskabelig eller humanistisk-samfundsvidenskabelig teori. Det andet modul er praktisk-teoretisk og indeholder tre-fire studieelementer. Der tilstræbes, at fælles temaer, studieopgaver, og i ét tilfælde fælles eksamen, binder det vidtfavnende studieindhold sammen.

På Institut for Idræt er videooptagelser af de studerende afprøvet med succes som et væsentligt element i fagets studieprocesser. Det har været motiverende for underviserne gennem en årrække i takt med IT-udviklingen løbende at formulere ønsker for udvikling af nye, enklere IT-video arbejdsstrukturer og anvendelse af tidssvarende studiefaciliteter. Videooptagelser indgår ofte som redskab i studieopgaver med feltarbejde og i forskning til kvalitativ analyse af f.eks. idrætspraksis i skolen.

\section{En kickstart på at studere et praktisk fag (studieteknik og vandbasis)}

\section{Første studieuge i Blok 1}

Studieelementerne studieteknik og vandbasis samarbejder i første studieuge. Det handler om at se på praksis med nysgerrige øjne, at sammenligne og diskutere, samt at udveksle konkrete oplevelser og erfaringer hentet både fra praksis og fra teori-pensum.

Modulets formål er, at de studerende i praktik og teori får en bred og eksperimenterende indgang til idrætsfagets basale kerneområder inden for bold-, krops-, og vandaktiviteter; samt at de studerende erhverver sig viden og redskaber til at kunne opfylde de krav, der stilles for at kunne studere Idræt. Denne tilgang til det praktisk-teoretiske modul danner grundlag for den videre og mere direkte udviklingsorienterede tilgang til praktik i de følgende blokke.

Faglige kompetencer omfatter, at de studerende udvikler deres kropsbevidsthed og får praktiske erfaringer med og teoretisk kendskab til betydningen af de grundlæggende og tværgående elementer i vand-, krops- og boldbasis.

Omverdenskompetencer består i, at de studerende gennem egne erfaringer og refleksioner udvikler en basal forståelse for det komplekse samspil mellem de kropslige, sociale, psykofysiske og mentale processer i forbindelse med basisfagene.

Anvendelseskompetencer er, at de studerende gennem deres egen læreproces får indsigt i de til mange målgrupper overførbare værdier, der ligger i arbejdet med basisfagene.

Personlige kompetencer består $\mathrm{i}$, at den enkelte studerende udvikler egen grundlæggende kropsbevidsthed og samarbejdsevne samt evnen til at reflektere over praksis og egen læring i relation til anvendt teori.

Studieaktiviteten relaterer delvis til traditionel (lærebogs-)litteratur, men i stigende grad indgår i pensum artikler fra nettet bl.a. med videoklip. Billeder og tegninger fra bøger, (der har været på vej længe og måske er mindre aktuelle) har forfatteren lært meget af at finde og udvælge. Inspireret af denne læreproces lægges der på flere kurser på IFI stor vægt på at lade den studerende finde "det gode billede" som egner sig til at blive et motiverende omdrejningspunkt /fokuspunkt, når den gode opgave skrives.

Et typisk forløb med "Videoklip - intro basis” kan se ud som følger 


\section{Trin 1:}

Til en forelæsning inden første videooptagelse skal den enkelte studerende i et skema kort skrive om egen erfaring med en vigtig oplevelse med vand, samt hvad gør han sig umage med, når han svømmer. Det ved de studerende faktisk ikke. Det er næsten umuligt for dem at formulere sig i relation til svømning. Jeg holder fast. De skal skrive udsagn om, hvad de oplever som svært, eller hvad deres ønske om forbedring er. Hvad vil de fokusere på, når de "skal vise kameraet" to stilarter og en vandtrædning. Dette er et forsøg på at starte billeddannelse og visuel forståelse hos den enkelte.

Skemaerne samles til senere viderebearbejdning i en studieteknik-lektion. Vi diskuterer samlet forskellige udsagn og ønsker. Vi bliver enige om nogle gode råd.

\section{Trin 2:}

Vi går i svømmehallen, først med lidt opvarmning og en afprøvning af de gode råd. Herefter videofilmes de studerende, som svømmer to og to. De optages fra fire kameravinkler samtidigt. To vinkler optages med stationære kameraer anbragt under vandet, et på langsiden og et for enden af bassinet, og to vinkler optages fra bassinkanten. De to undervandskameraer overvåges ved hjælp af tilsluttede monitorer i svømmehallen og panoreres fra samme centrale plads ved hjælp af joysticks. De to kameraer på bassinkanten er håndholdte, digitale videokameraer, der på skift betjenes af de studerende.

Institut for Idræt har sammen med IMC Copenhagen - som det foreløbig seneste skridt i processen med at inddrage video i studieprocessen - udviklet et web-baseret IT-system, der kan konvertere og distribuere videosekvenserne i en automatiseret - og dermed hurtig arbejdsgang. IT-systemets foreløbige navn er "IFI Video".

Teknikken og brugergrænsefladen er som følger: De fire kameraer (to digitale og to analoge), der bruges til de samtidige optagelser, er forbundet med coax-kabler til hver sin konverteringsboks, AXIS 250S MPEG-2 Video Server. Når videosignalet når AXIS-boksen konverteres det "i flugten” til MPEG-format og sendes i denne komprimerede udgave videre til en egentlig konverteringsserver, der befinder sig et andet sted på instituttets lokalnet. Når videoklippene rammer denne server behandles de automatisk i et konverteringsprogram fra Canopus, i første udgave en ProCoder konverteringskerne, i anden udgave er den erstattet af konverteringskernen Rhozets Carbon Server. Konverteringsprogrammet omdanner videoklippene til nogle mere håndterbare størrelser og formater. På IFI præsenterer vi de færdige klip i wmv- formatet, der er udviklet til Microsofts Windows Media Player. De færdige, konverterede videoklip lagres centralt på en filserver på IFI’s lokalnet.

Optagelserne styres af underviseren fra det web-interface, IMC har udviklet til brug under Microsoft Internet Explorer.

Fra operatorpanelet, vist i Figur 1, kan underviseren styre optagelserne og beslutte, hvad de færdige filer skal hedde (generisk - navnet udvides automatisk med dato og tidspunkt), hvilke vinkler der optages fra, hvilke studerende der skal have adgang til den aktuelle optagelse, samt hvilke nøgleord i form af teknikker / begreber der skal fokuseres på.

Når valgene er foretaget, startes og stoppes ved klik på de respektive knapper. De hele sker på underviserens bærbare computer, der er taget med i svømmehallen og koblet på IFI’s lokalnet.

Når de studerende forlader svømmehallen, kan de gå på nettet og umiddelbart se optagelserne af sig selv og dem, de er filmet sammen med i bassinet. De får adgang til den aktuelle studiegruppes optagelser og ofte også til en opponentgruppe, således at grupperne kan interagere og udveksle gode råd. 


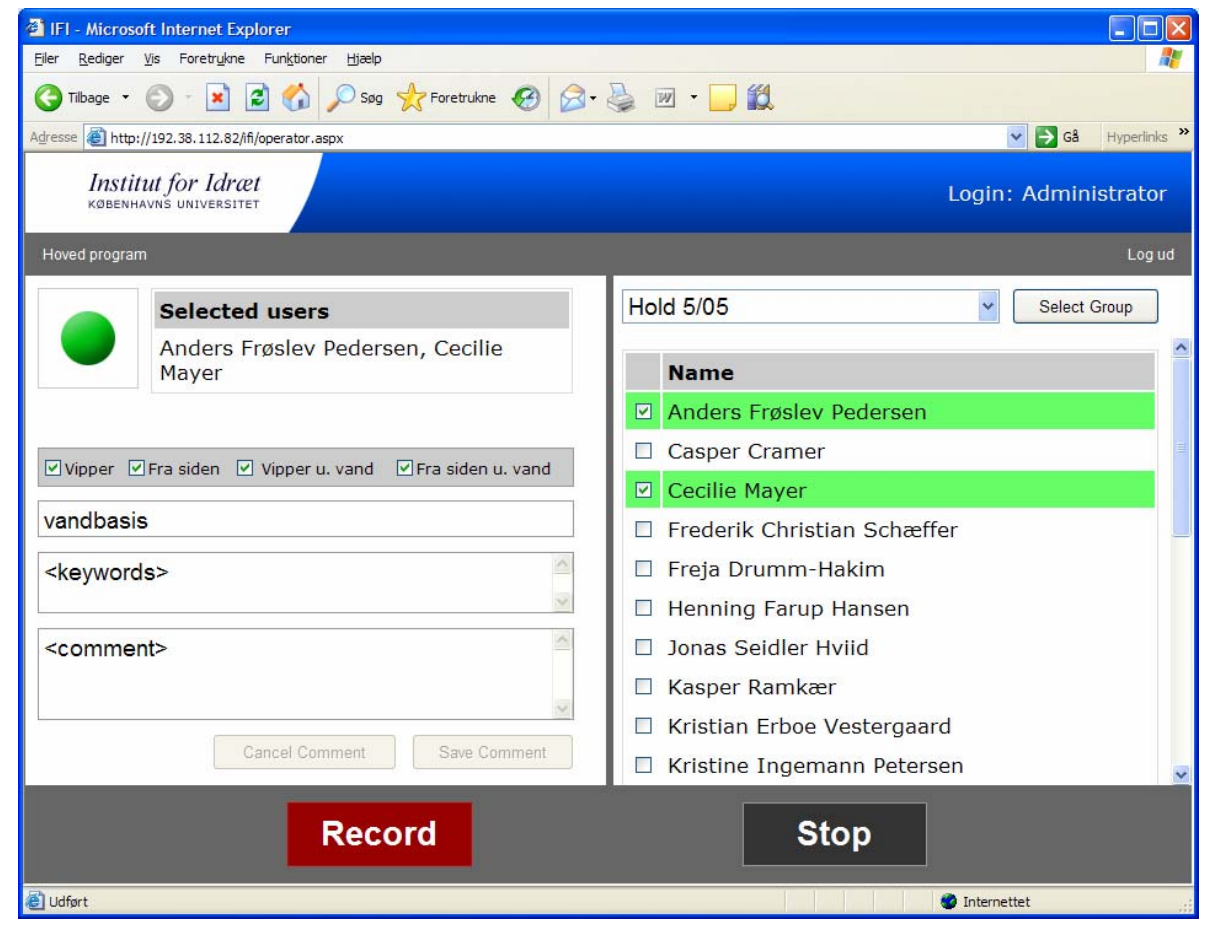

Figur 1. Underviseren forbereder optagelse

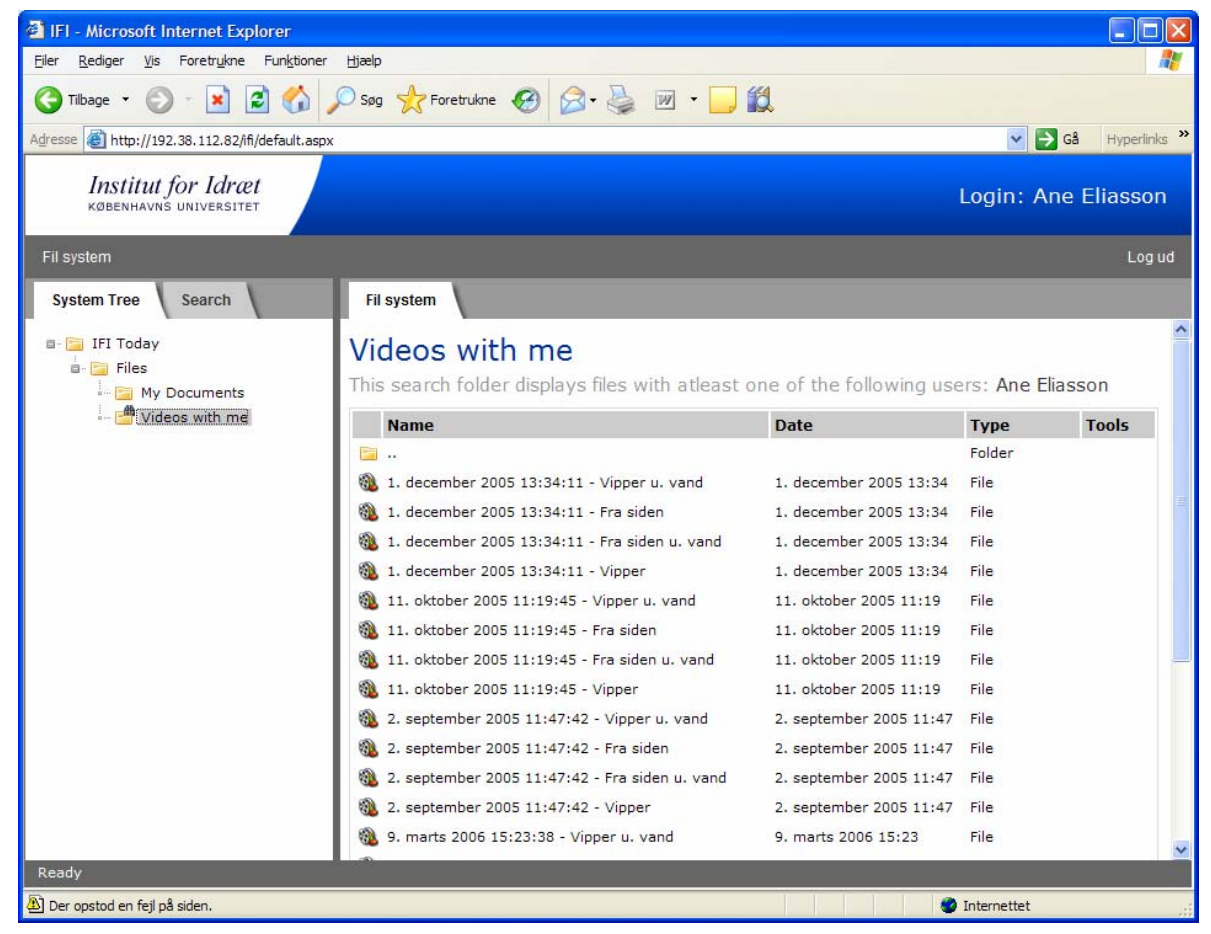

Figur 2. Den studerende ser en oversigt over egne klip

Ved studiestart samkøres stamoplysninger på den studerende med IFI Video-systemet. Det betyder, at de studerende kan bruge deres personnummer og deres KU-selvbetjenings PINkode til at logge på systemet ved hjælp af deres internetbrowser. Systemet er lavet sådan, at den studerende automatisk får præsenteret alle de klip, hvor han selv er med, dvs. hvor underviseren har tilføjet den studerendes navn til et aktuelt klip. 


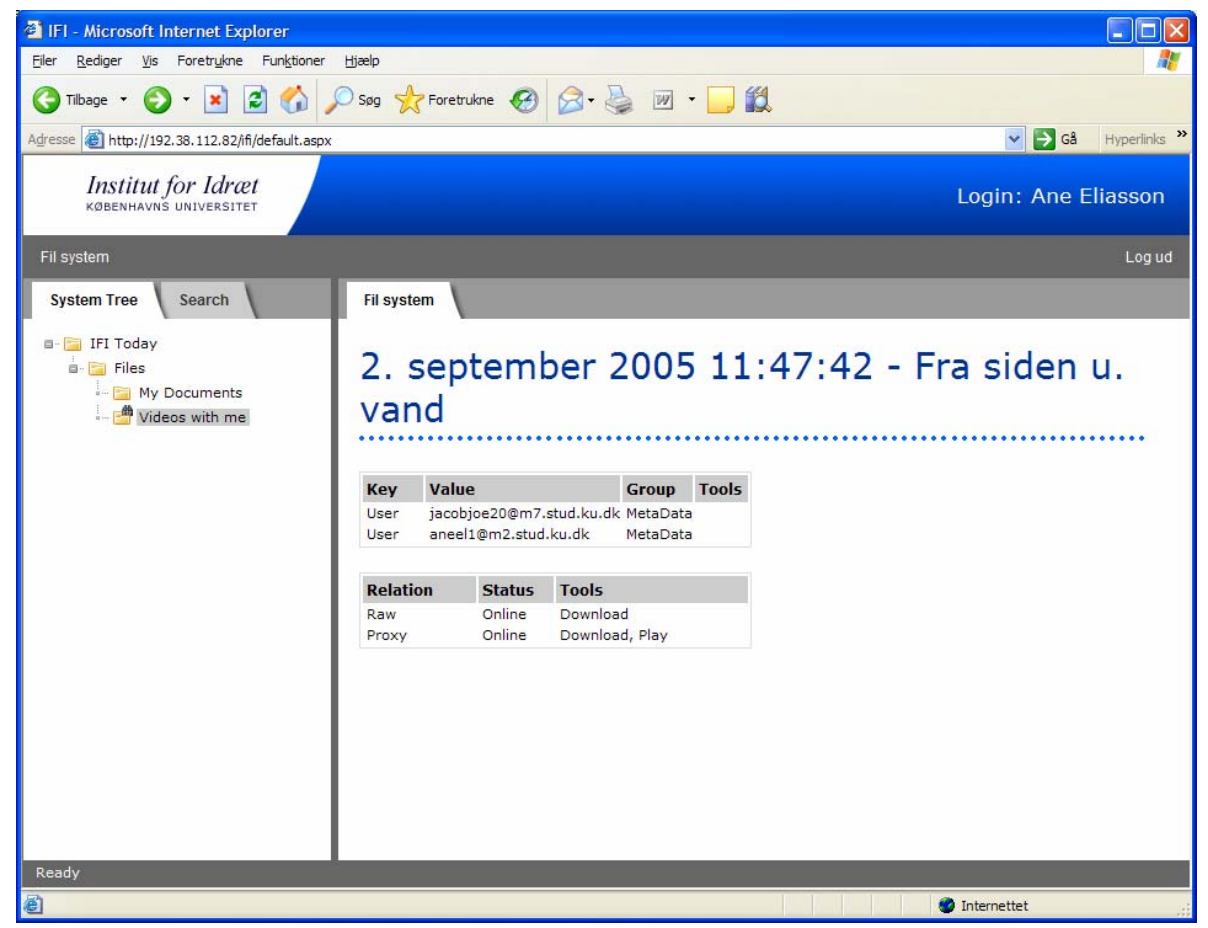

Figur 3. Den studerende har valgt et klip

Den studerende har flere valgmuligheder, når han har fundet det aktuelle klip. Han kan afspille den konverterede (wmv) udgave over nettet (Play, se Figur 4), hente den konverterede udgave ned på egen pc til efterfølgende afspilninger (god ved langsomme netopkoblinger) og endelig hente det "rå" videoklip, i avi-format, ned på egen pc for efterfølgende behandling i et videoredigeringsprogram, f. eks. til udvælgelse og klip af mindre sekvenser og still-fotos af høj kvalitet.

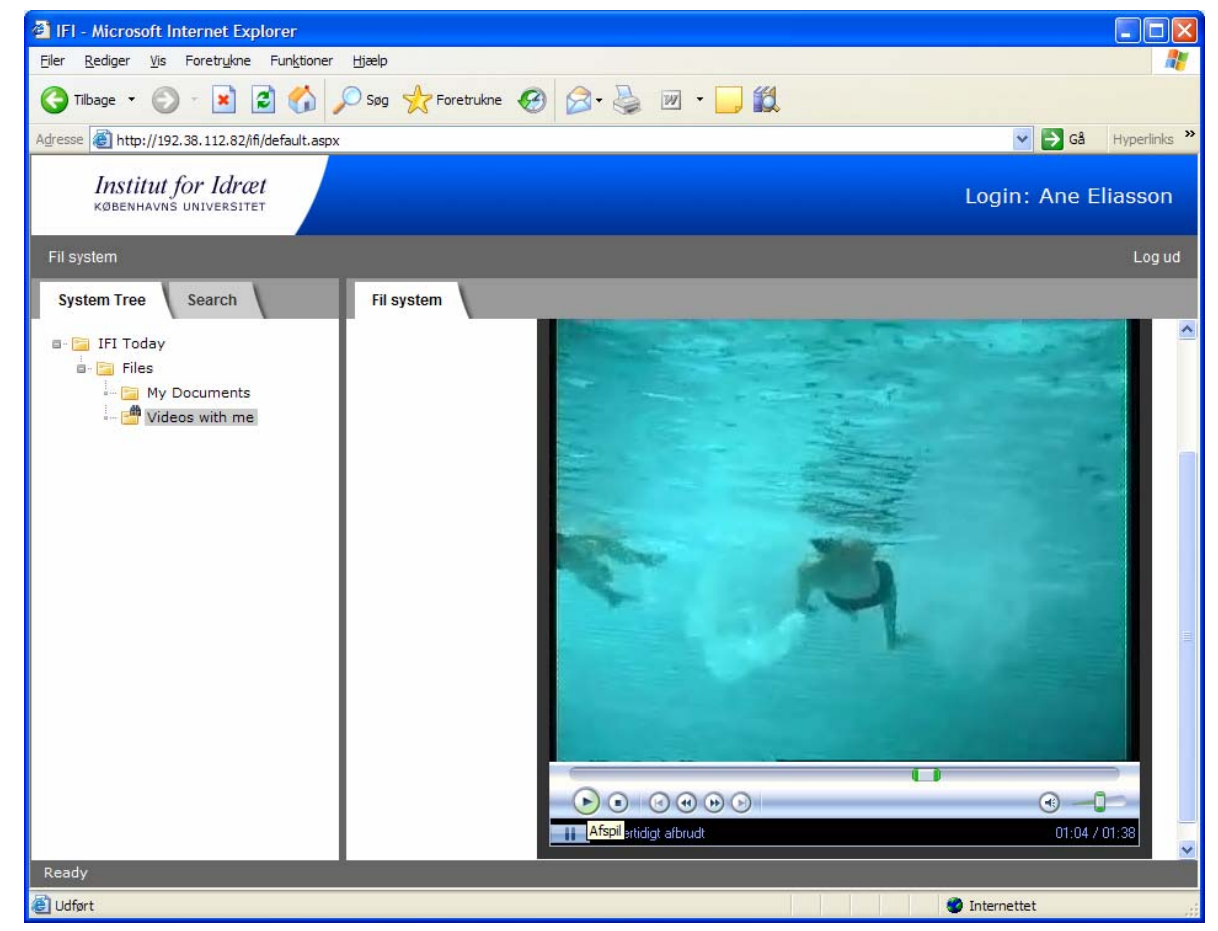

Figur 4. Den studerende afspiller video vha. plug-in 


\section{Udvikling af IFI Video}

Processen har været lang med mange omveje og nye ideer et opstået undervejs. Udviklingen har været moralsk støttet af nysgerrige studerende og kolleger. Interne IT-folk har tålmodigt støttet, når der har været brug for dem. En motiverende opmærksomhed fra NIK og CND har været en uvurderlig hjælp. Og ikke mindst har den største økonomiske finansiering fra TRYG-fonden været altafgørende for igangsætningen.

Og nu tilbage til et hold studerende, som er optaget på video i svømmehallen første gang. Scenen er undervisning i studieteknik i pc-kælderen på August Krogh Instituttet:

\section{Trin 3:}

Et par dage efter sidder vi i pc-kælderen for at analysere, finde og klippe spændende billeder til print, tegneøvelser og til dialog. Det gode billede ... er et illustrativt eksempel, som klippes ud af filmoptagelserne for at fastholde situationer til nærmere analyse og refleksion. Begreberne kommer i spil. Herudover afprøves forskellige muligheder for samarbejde med kursuswebsiderne ISIS, f. eks. opgaveaflevering. Den individuelle nysgerrighed viser forbløffelse ...."uha ,ser det sådan ud?”, ”Jeg troede jeg gjorde...Hvor er det tydeligt...afslørende”. Nu er snakken hurtigt en helt anden. Grupperne undrer sig over den store mangfoldighed af bevægemønstre. Nysgerrigheden er vakt, og der bliver gået på opdagelse. Personlige erfaringer og mere teoretisk viden forbindes på måder, hvor den enkelte studerende føler ansvar og mening. Sammenhæng mellem teori og praksis skabes i en proces der involverer alle aspekter af læring i dialog med stoffet. ... Studiet er i gang.

\section{Et eksempel på "det gode billede"}

På videoen kan man se, at pigerne følges i fin rytme. De holder pause samtidig, den ene møder meget modstand i glidepausen!

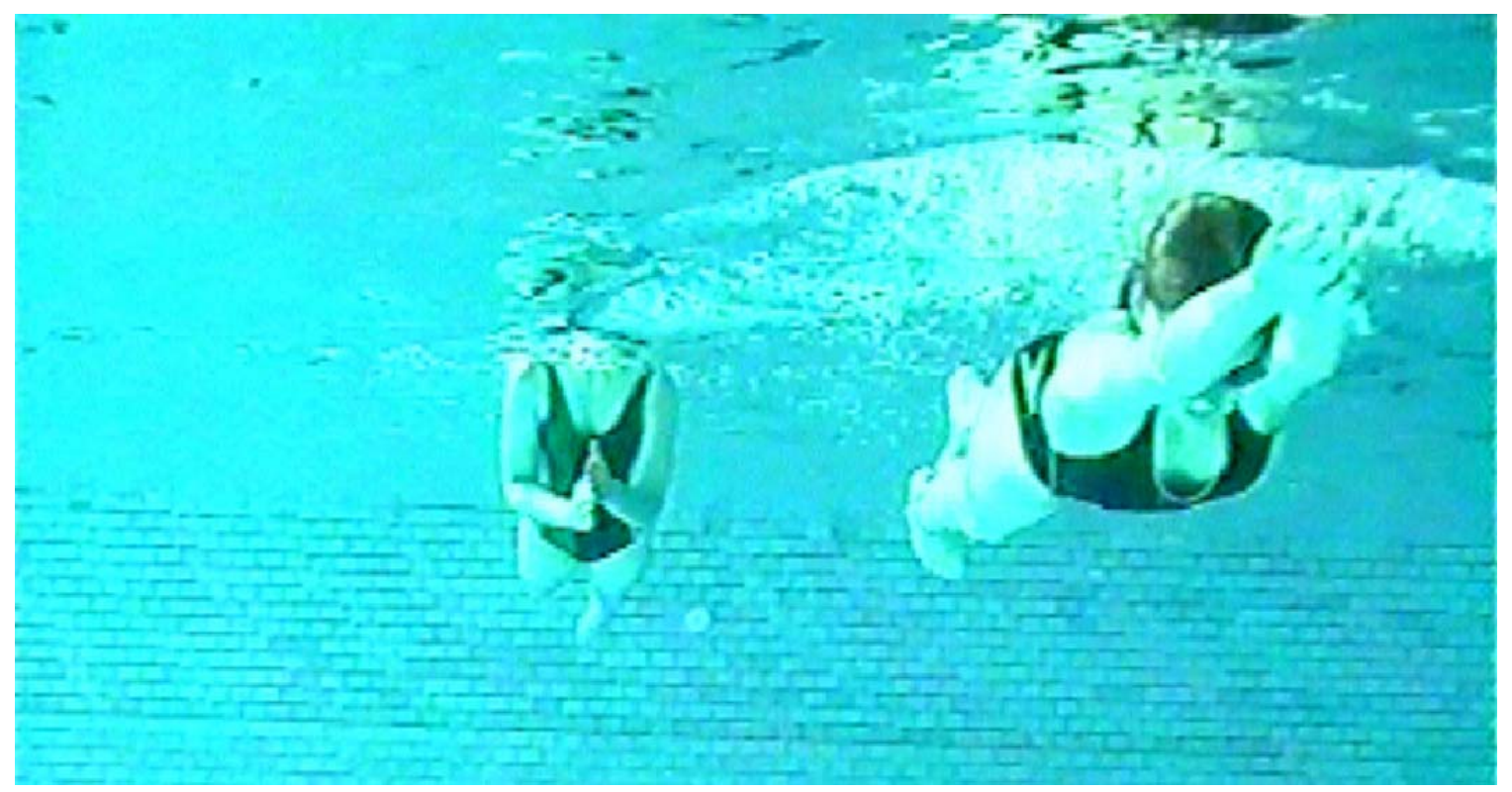

Figur 5. Det gode billede. De 2 piger har glidepause her! 


\section{Trin 4:}

Studieaktiviteten kan løbende fortsætte hjemmefra, da videooptagelserne er tilgængelige online. De konverterede klip kan streames eller downloades. De to øvelsesgange i en stor pckælder, som hvert hold har i studieteknik, sikrer, at alle studerende har færdigheder til at indgå i de IT-video planlagte studieprocesser. At kunne forberede sig til tilstedeværelseslektioner via nettet, se på gruppens og egne videoer og relationen til undervisningsmateriale på webstedet har stor betydning for studieudbyttet. Udvikling af praktisk færdighed på kort tid støttes af denne visuelle forestilling af, hvordan det ser ud (endda fra flere vinkler) og opleves. Ved fravær, sygdom, ønske om intens fordybelse giver online-adgangen af sig selv en populær mulighed for selvstudie. Så populær er den, at jeg efter fagdidaktisk overvejelse løbende er nødt til at katalysere de øvrige kommunikationsprocesser i studiearbejdet. At se og forstå bevægelsesadfærd hos medstuderende er en nødvendig øvelse at deltage i.

\section{Syvende studieuge i blok 1}

\section{Trin 5:}

I de første fem studieuger har undervisningen fokuseret meget på at lære en arbejdsmetode til initiering af en "IKT-læreproces” med den hensigt at opleve teori-praksis sammenhæng, samt at få indsigt i værdien af at inddrage IT og video i kommunikationsprocessen mellem de studerende.

Det svømmefaglige fokus intensiveres i de sidste to uger. Praktisk og teoretisk færdighed skal evalueres. I studieuge 7 videooptages den studerende igen ved fremvisning af sin opnåede praktiske færdighed - 50m rygcrawl med funktionel start og vending. I en afsluttende opgave beskriver og vurderer den studerende sin svømning via denne optagelse i relation til den gennemførte (lære)proces. Det er et krav til besvarelsen, at den studerende - foruden litteraturhenvisninger benytter billeder fra videooptagelsen som dokumentation.

Opgaven afleveres på nettet i opgaveaflevering på kursus-webstedet. Her gives der mulighed for kommentarer mellem underviser og studerende både formelt og uformelt og på en behagelig måde.

\section{"En god (nok) opgave"}

Hvordan skriver de studerende så en opgave, hvor de viser at de er kommet godt i gang med at studere et praktisk fag? Og hvordan opnås relevant studieudbytte?

Kontrol af opnået studieudbytte er ofte aflevering af en opgave, som viser at der er opnået forståelse af relevante faglige begreber og at disse kan anvendes konkret i beskrivelse af udvalgte situationer i studieprocessen.

Visionen for opnåelse af optimalt studieudbytte i og omkring den enkelte lektion i svømmehallen stiller krav til, at det er muligt både at afprøve, få ny erfaring, reflektere og være i dialog, såvel i vandet som på kanten. Denne vision er svær at leve op til i lektioner på 45 minutter., med 28 studerende, og med stor spredning i praktisk færdighed og viden.

Videoanalysen som arbejdsmetode i relation til praksis er derfor specielt udviklet til at støtte studieprocessen ved hjælp af det særligt udviklede online praksis-teori system, IFI-VIDEO.

At stille krav om billeddokumentation i opgaven er derfor naturlig.

Her følger eksempler fra to opgaver. Opgaven Steen er kun repræsenteret med to billeder og korte udsagn, mens opgaven Jens er gengivet i sin helhed. 


\section{Opgaven "Steen"}

"Da jeg svømmede de 50 m rygcrawl, følte jeg egentlig, at jeg lavede en god start, med et langt glid under vandet. Men jeg kan nu godt se, når jeg ser videoklippet, at det er langt fra perfekt. Det, der falder mest i øjnene, er min placering af hovedet. Det vender helt bagover, så jeg kigger frem af, hvor jeg svømmer (fig. 1). Dette gør selvfølgelig, at jeg laver en masse modstand i vandet og forringer glidet betragteligt. Min kropsholdning er også lidt kramagtig og jeg får ikke lavet nogen synlige bølgebevægelser. Hvis jeg skal fremhæve noget positivt, så må det være, at jeg har fået tilført en masse kraft i starten, så på trods af de unødvendige kropslige modstande, kommer jeg faktisk ret langt under vandet.”

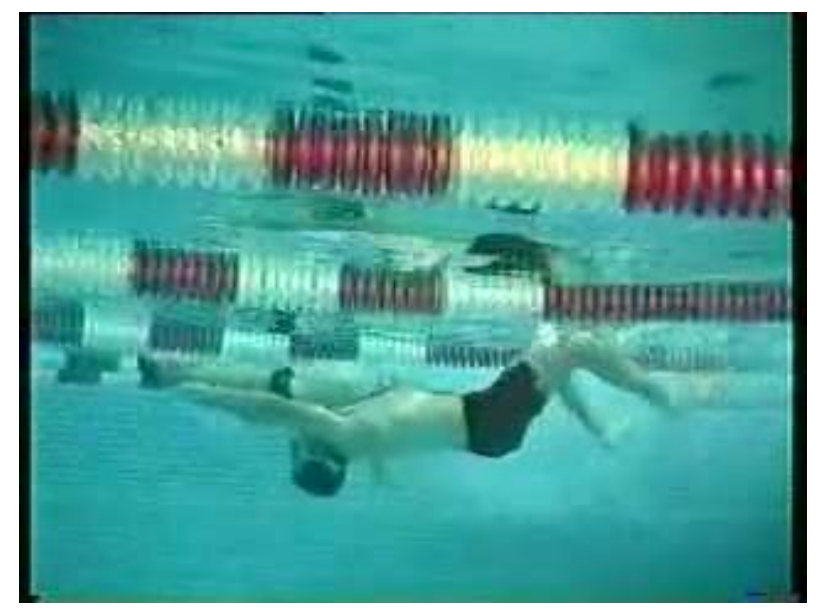

Fig. 1. Starten. Hovedet alt for langt bagud og benene er forkert placeret.

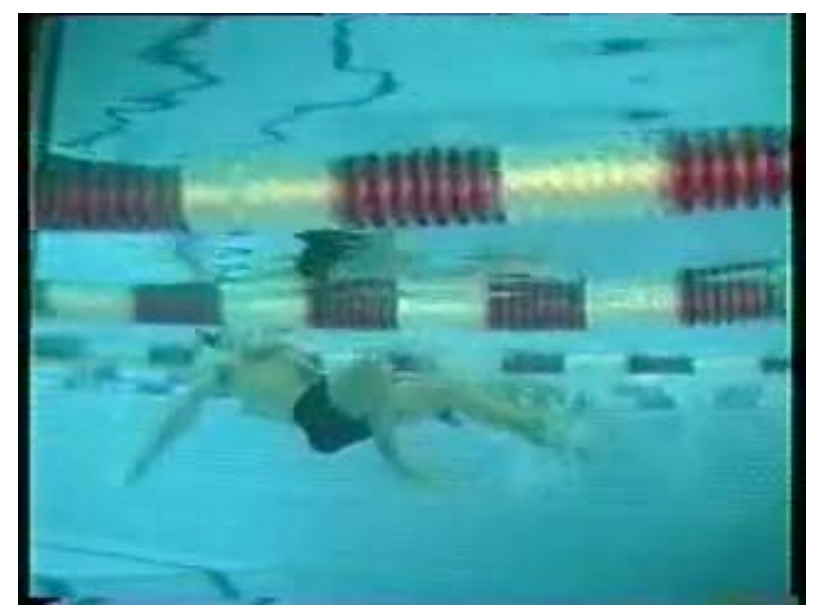

Fig. 2. Ringe kontrol over tyngdepunktet omkring navle. Benene er ikke strakte.

"Balancen i vandet:

Det er ret tydeligt, at jeg har nogle problemer med, at finde balancen i vandet. Dels synker mine ben mod bunden og dels er mine ben ikke samlede (fig. 2).

... men som man kan se på optagelserne, så er det som om jeg har et "tilbagefald" så snart jeg skal koncentrere mig om alle elementerne i rygcrawl.

Det er ret tydeligt, at det er benarbejdet jeg har flest problemer med. Jeg har desværre en tendens til at "cykle” af sted, når jeg mister fokus på benene. Dette ses også tydeligt på fig. 2, hvor mit højre ben er næsten helt bukket sammen. De burde være strakte og arbejdet skal gerne komme af bevægelser der udspringer fra hoften.” 


\section{Opgaven "Jens"}

"Rygcrawl

1) I startposition sidder man i en spændt "vandret hug" stilling, med fødderne lige under overfladen, mens armene holder fast i "startbøjlerne" så overkroppen holdes oven vande. Afsættet afvikles ved et spring, hvor armene føres sammen bag over hovedet, så kroppen strækkes i et svaj mod vandet. Jeg har dog problemer med at komme helt fri af vandet, så jeg ikke bare plasker ned oven på vandet og mister en masse fart fra afsættet.

Efter afsættet skal jeg holde gliddet lidt længere, så jeg får mest muligt ud af afsættet.

For at optimere kroppens glideevne skal kroppens form tillade vandet at strømme rundt om og forbi kroppen med minimal turbulens. I den perfekte strømlinede position er kroppen placeret vandret i vandet med armene strakt frem foran hovedet, med ansigtet vendt mod loftet. Mave og baller holdes spændte, så kroppen opretholder en ret position i vandet. Knæ og fodled strækkes så mindst mulig turbulens opstår. Jo mere strømlinet position kroppen har, des mindre vandmodstand. Ved start og vending vil den strømlinede position altså resultere i højere fart og længere glid.

Omkring rotationen mangler jeg en hel den øvelse. Jeg får ikke roteret skulderen halvt så meget som optimalt og skubber derfor en masse vand ud til siden.

I rotationen er det vigtigt at skuldre og hoften roterer på samme tid, mens hovedet skal holdes stabilt i samme stilling med ansigtet mod loftet. Nederste arm skal holdes fremme ind til øverste arm er nået forbi lodretstillingen. Herefter gennemføres taget med nederste arm, med flekteret albueled i en lige linje mod hoften. Øverste arm føres nu i vandet og kroppen roterer helt om på den anden side.

Benene skal jeg arbejde med at få til at ligge mere vandret, da de hænger en lidt lavt og derfor ikke særligt aquadynamisk. Samtidigt skal jeg arbejde med at strække benene så sparket kommer til at ligge i hoften og ikke i knæledet som nu er tilfældet.

Bensparket skal hovedsagelig afvikles i hoften, mens knæ og fodled skal holdes næsten strakt. Sparket skal foregå i en glidende bevægelse og holdes under overfladen så vandmodstanden holdes på et minimum.

Tendensen til at benene synker skyldes dels at tyngdepunktet ligger nærmere benene (omkring navlen/hoften), end opdriftspunktet (omkring lungerne) og dels at kroppen ikke er helt spændt. Balancen kan genoprettes ved at holde mindst én arm foran hovedet. På den måde flytter man tyngdepunktet længere op mod opdriftspunktet. Derudover skal man spænde i mave og baller, så kroppen bliver stabil.

2) Jeg er allerede blevet bedre til at ligge mere vandret $i$ vandet, end jeg var ved den første filmning. Således får jeg mere fart ud af mit arbejde og et længere glid. Der skal dog stadig arbejdes med bensparket hvor jeg stadig bøjer knæene for meget, og arbejder for lidt med hoften.

3) Når jeg skal arbejde videre med teknikken i rygcrawlen vil jeg fokusere på balance i vandet, rotationen og bensparket. Rotationen som det første da det er en essentiel del af rygcrawlen at man for roteret kroppen korrekt. Dernæst bensparket da det tager for meget energi at ligge og sprælle sådan med benene og fordi det også er vigtigt i forhold til den almindelige crawl.

Jens

Gruppe: Peter, Søren og undertegnede” 

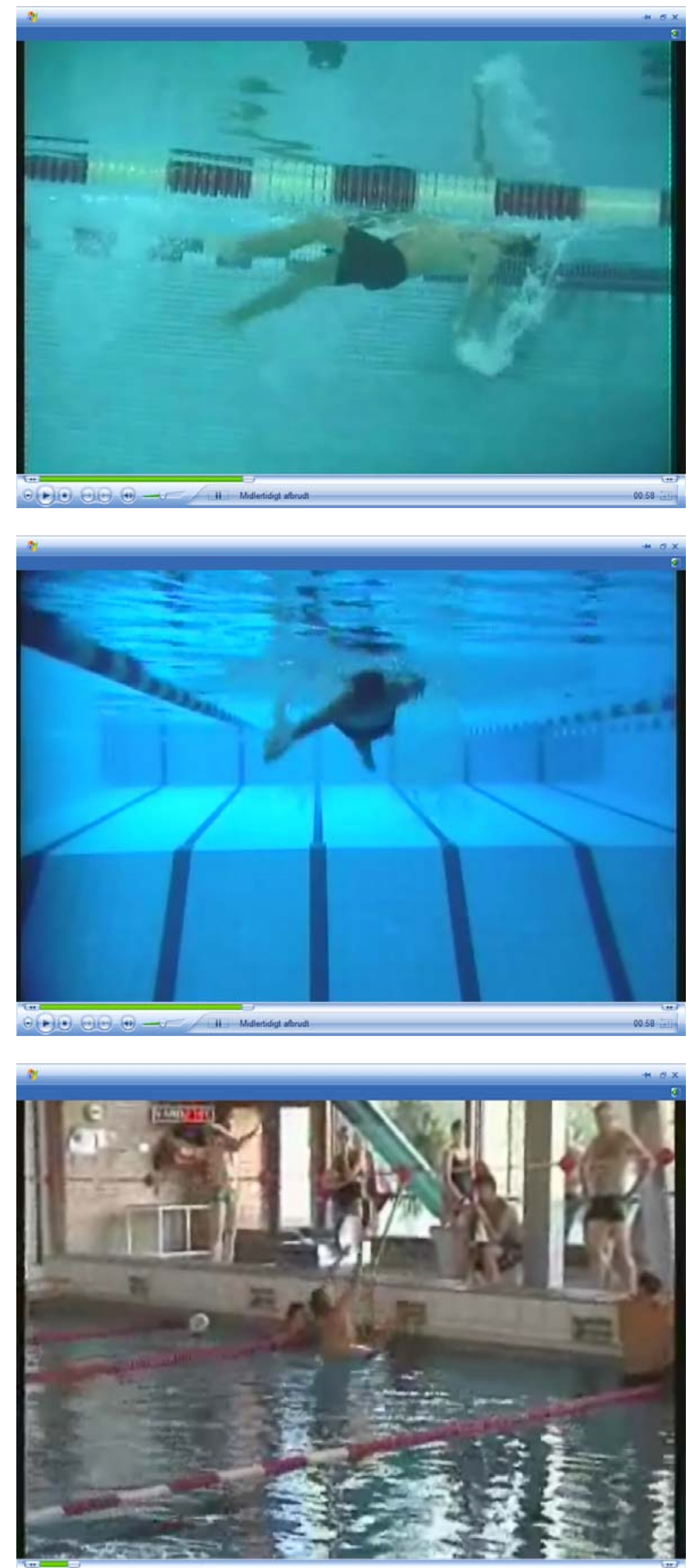

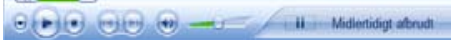

0007 
Opgaven Jens er medtaget i sin helhed. Den viser, at Jens klart har opnået de ønskede kompetencer. Herudover er det lykkedes Jens at formulere en masse gode råd til sig selv. Han er positivt konstruktiv, medtager mange begrundelser, hvor han integrerer teori.

Videoklip giver, som her illustreret, mulighed for at se praksis i eget tempo, gentage, undre sig, tage et billede f. eks. under vand, sammenligne, diskutere med gruppen og litteraturen. Hvad foregik der? Hvad vil jeg koncentrere mig om i næste lektion? Ved fravær støttes muligheden for at samle op på dele af processen.

\section{Ny blok, nyt kursus, nye udfordringer}

\section{Kravene øges - kommunikationsveje i gruppeprocessen}

De mål, der er opsat for studiemodulet Livredning og sikkerhed i blok 2 og de aktuelle kompetencebeskrivelser der styrer planlægning af studieelementet beskrives sådan:

Formål: Det er hensigten med dette faglige studieelement at den studerende opnår kompetence til at

- på ansvarlig vis at kunne lede aktivitet i vand,

- formidle adfærdsmønstre, der giver positive oplevelser ved ophold i vand og medvirker til at forebygge ulykker i og ved vand,

- administrere viden om et funktionelt samarbejde mellem krop og vand,

- vurdere egen og andres reaktioner i forbindelse med ophold i vand under vekslende forhold herunder at bearbejde handlingsmønstre og normer for adfærd i grænseområdet mellem angst, udfordring og leg.

I forbindelse med praksis skal den studerende udvikle alsidig færdighed i selvredning, få indsigt i at standse en ulykke og lede en redningsaktion, samt opnå færdighed i at redde andre.

Der arbejdes med: svømning under vand, vandtrædning, dykning, bjærgning af træt /bevidstløs/panisk svømmer, ophaling, teoretisk kendskab og introducerende praktisk færdighed i trinvis førstehjælp, og nordisk livredning. Svømning i åbent vand (søsportsprøve) afvikles i juni. Livredningsteori inddrages i forbindelse med afvikling og diskussion af cases.

Der stilles øget forventning til studieprocessen med hensyn til:

- at synliggøre teorier,

- at øge brugen af kommunikationsveje

Det vil sige, at der konkret stilles krav til udvalgte fokuseringer fra processen om billededokumentation og anvendelse af litteratur.

Og "at give et godt råd” internt i gruppe anvender såvel begrundet vejledning både på bassinkanten, i gruppeteori lokale, i pc-kælderen og online.

Studieprocesserne i denne blok forholder sig meget bevidst til at forstå og håndtere angst.

Ved videoanalyse af bevægelsesadfærd tidligt i forløbet giver det gruppen mulighed for at tolke på årsagen til de refleksbetonede uhensigtsmæssige forstyrrelser der optræder ved udførsel af "livredningsfærdigheder”.

Det er hensigtsmæssigt at de studerende på dette tidspunkt er kompetente til at anvende IFIvideo og er motiveret til at fortsætte denne udvikling/inddragelse af IT i studiearbejdet. 


\section{Opgaveformulering}

\section{Livredning - Videoanalyse}

“Gruppeopgave i Blok 2, studieuge 3-7

Opgavens formål:

Hensigten med at inddrage videooptagelse i studieprocessen er at forbedre den studerendes forståelse for, at såvel tekniske, erfaringsbaserede som psykologiske aspekter er væsentlige ved udvikling af færdigheder inden for livredning.

I mindre grupper får den studerende lejlighed til at reflektere over sammenhæng mellem teoretisk viden, det visuelle billede og den oplevede erfaring. Studieopgaven træner observation af teknisk færdighed og giver erfaring med at fokusere på såvel primære, som generelle detaljer.

Gruppens medlemmer har de kommende studieuger til at vejlede hinanden og følge op på processen indtil evaluering af de praktiske færdigheder i blokkens 8. uge.

Indhold:

I grupper på tre studerende udvikles denne vejledning. Den enkelte forbereder gode råd både til sig selv og de 2 andre.

Gruppens medlemmer kan via videooptagelserne på IFI-video give hinanden gode råd (enkle, positive, få sætninger, kort begrundet). Studiearbejdet med videoanalyse og billedklip giver mulighed for refleksion og dialog, så den studerende samtidig kan indgå aktivt i såvel egen som andres studieproces.

Eksempel på spørgsmål til refleksion over:

- Hvorfor ser det sådan ud? Hvor er mit udgangspunkt? Hvad gør jeg rigtigt? Hvad kan jeg forbedre?

- Hvorfor se på en svømmer fra flere sider? Hvad ser du fra længden, fra siden og fra oven?

Ved dialog og vejledning til en anden er det godt først at

- beskrive 1-2 detaljer eller helheder der fungerer godt (suppler med begrundelse),

- og herefter giver du positiv vejledning / dit gode råd, som begrundes.

Studiearbejdet fortsætter i gruppen, indtil evalueringen er afsluttet for den enkelte.

Opgaveaflevering:

Som afslutning på studieopgaven afleveres en beskrivelse af de vigtigste fokuseringer, gruppen har arbejdet med.

Hvilken vejledning har I givet hinanden? Hvordan har I modtaget denne?

Hvad er du / I blevet bedre til? Begrund kort og prioriter de teoretiske elementers betydning for Jeres proces.

Forventninger til evalueringssituationen? Hvad skal den enkelte specielt koncentrere sig om? Hvordan vil I støtte hinanden?

1-2 spørgsmål udleveres til besvarelse i relation til opgaven i starten af 7 . studie uge. (1/2 S.)

Omfang max. 5 sider. 
Som bilag vedlægges billedklip af situationer, der har været væsentlige i Jeres studiearbejde.

Opgaven relateres til pensum fra Blok 1 og 2 med litteraturhenvisninger.

Hilsen Jørn, Mogens, Nikolai og Lillan”

Som det kan læses i opgaveformuleringen anbefaler vi, at det er videoklip af de studerende selv, som er katalysator i gruppeprocessen. En studerende kan hjemme klippe nogle billeder ud, som han vil bruge til dialog med de to andre i gruppen. Printet medtages til næste lektion.

Figur 6 viser et eksempel på billedklip, hvor muligheden for at have flere videoer/vinkler åbne anvendes De fire billeder kan hver især give anledning til begrundet ros med efterfølgende gode råd.

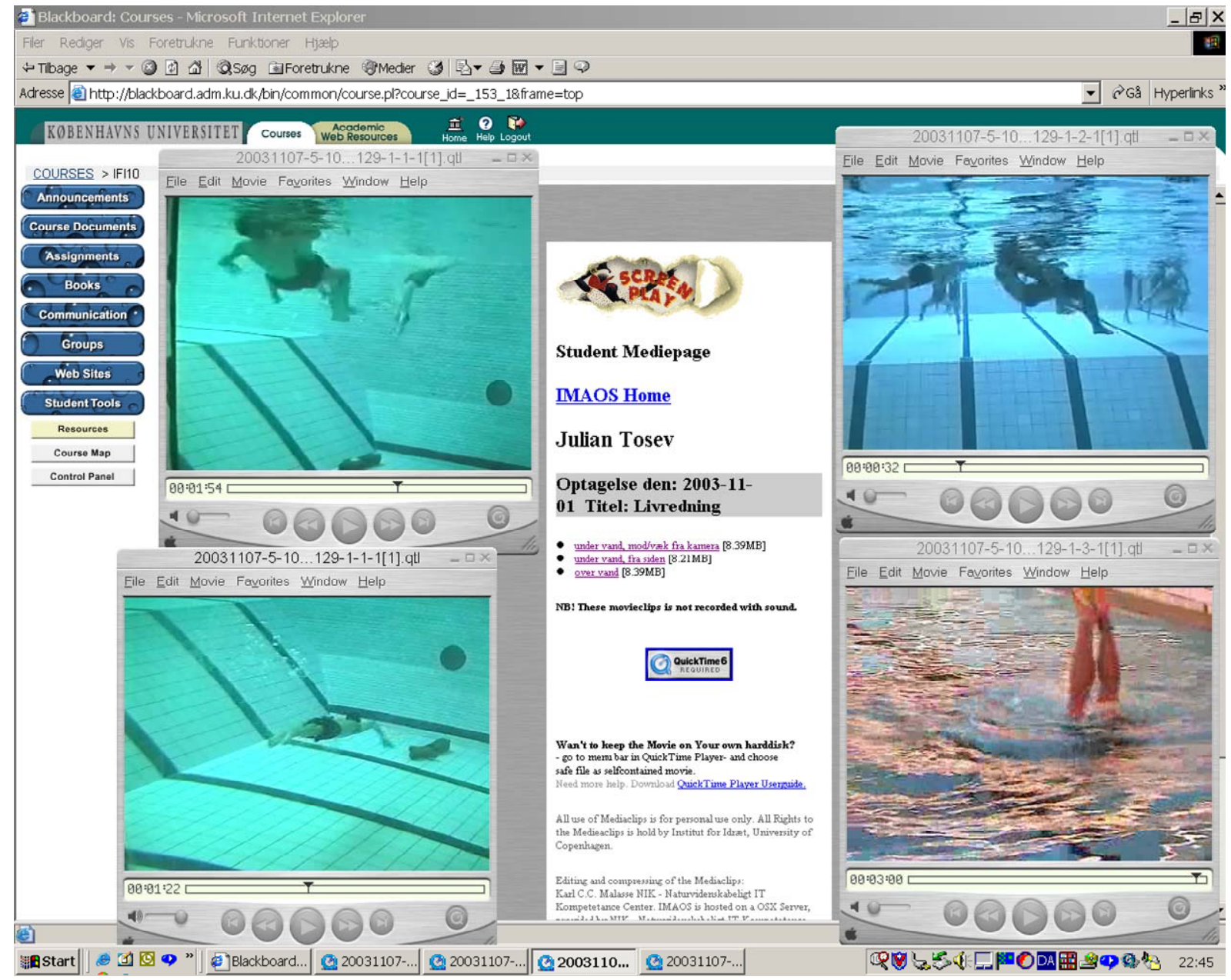

Figur 6. Fire samtidige afspilninger i QuickTime

\section{Den historiske udvikling}

Illustrationen, Figur 6, viser, hvor langt vi var nået i 2003. I det indledende kuvøseprojekt med støtte fra NIK var processen: først videooptagelse (analog video) af de studerende, overspilning af de analoge videooptagelser til digitale sekvenser på en pc (capture), på pc'en klippes optagelsen i mindre sekvenser med en eller få studerende pr klip, og på pc'en konverteres enkelte klip til et format, der egnede sig til distribution over internettet (valg af format 
ved konverteringen var et kompromis mellem billedkvalitet og filstørrelse.) I denne fase blev der stiftet bekendtskab med adskillige pc-værktøjer til brug i de tre arbejdsgange (capture / edit / make). Vi landede i en længere periode på pc-programmerne Storm Video fra Canopus til capture og edit og ProCoder, ligeledes fra Canopus til konvertering.

For at publicere de færdige klip hjalp NIK med konsulentbistand. Kim Ernest udviklede IMAOS, som lagrede klippene på en filserver og sørgede for, at der var link fra de enkelte studerende fra kursushjemmesiden i Blackboard til de enkelte videoklip, så de studerende kunne hente en kopi over nettet af deres egne optagelser. De publicerede klip blev gemt i QuickTime-format, og nogle af fordelene ved QuickTime-afspilleren - ud over at Apple stillede den gratis til rådighed - var, at man kunne starte et "ubegrænset” antal instanser af programmet samtidig, og man kunne under afspilning singlesteppe sig fra billede til billede med en nøjagtighed på 15 billeder pr. sekund. Dette var en fordel, når der skulle analyseres på optagelser fra fire vinkler samtidigt. Figur 6 viser et skærmdump med fire samtidige QuickTime-afspilninger.

"Kuvøseprojektet” var i en tidlig fase knyttet til et projekt, EduMedia, der arbejdede med multimediepræsentationer via internettet (se http://www.fsknet.dk/edumediamain).

Det var meget inspirerende at steppe frem og tilbage fordi funktionen var meget fintfølende. En tilsvarende funktion til at "lege” med 4 vinkler /videoer på samme tid er underudvikling til IFI-video (Se figur 7). Visionen for denne er at den kan blive ligeså fint følende som quicktime udgaven, at den kan steppe baglæns og spille i slow.

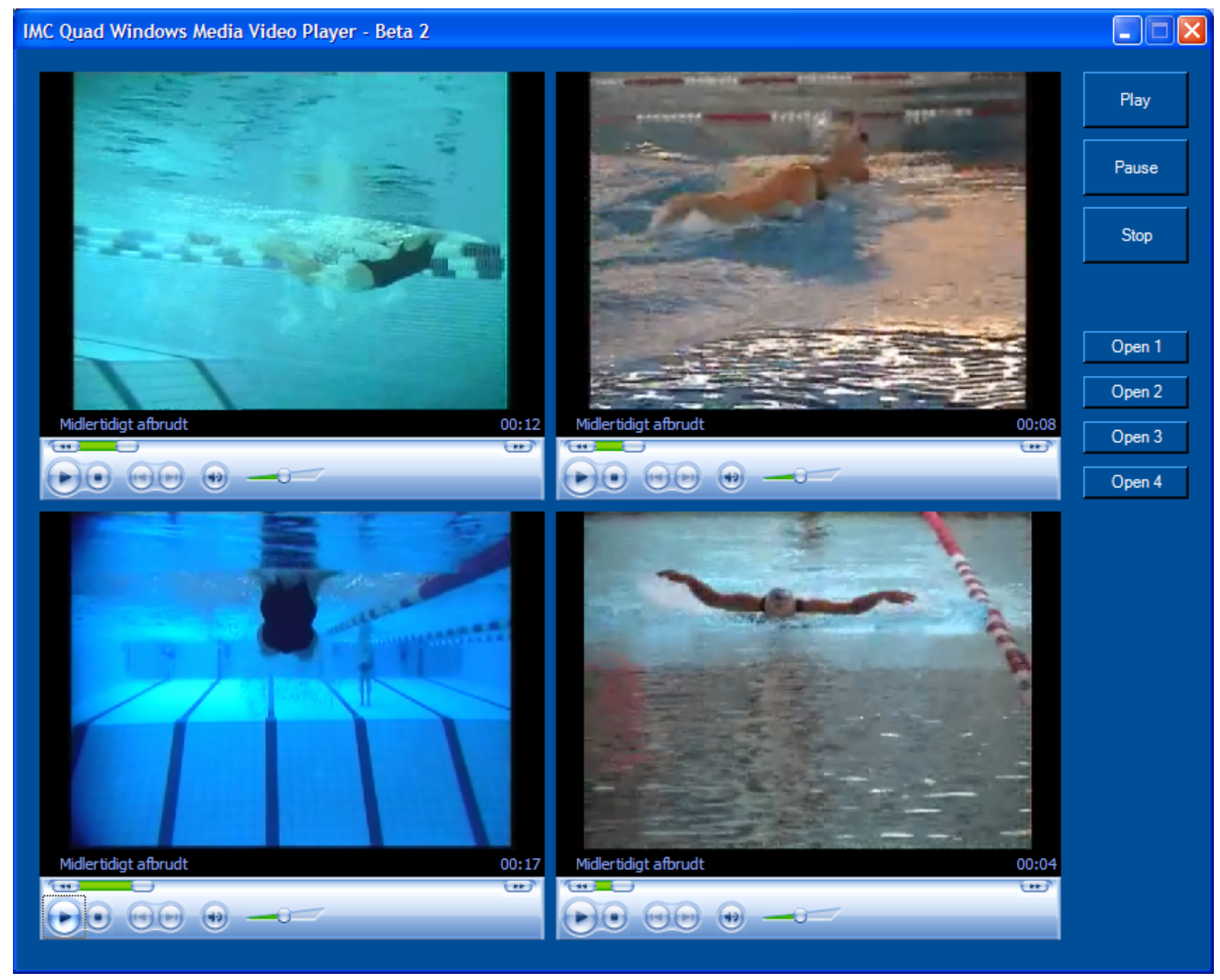

Figur 7, Ny IMC Windows Media Quad Player 


\section{Epilog}

Sidst på grunduddannelsen afsluttes med en eksamen, der afspejler studieprocessen med brug af IT og video. Det svømmefaglige indhold er de fire stilarter; gruppeprocessen støttes af en tidlig videooptagelse af $100 \mathrm{~m}$ medley. Den afsluttende eksamen foregår individuelt i pckælderen. Den afsluttende videooptagelse af praksis skjules i systemet indtil eksamenstidspunktet. Adgangen åbnes. Dette var en meget spændende teknisk udfordring for IMC (jeg havde optagelserne med på dvd som reserve). Videooptagelsen laves ca. to dage før eksamen. Gruppen giver mundtlige kommentarer til svømmeren.

Dagen før eksamen skal den studerende uploade en disposition, der omhandler hvad eksamensanalysen vil handle om i relation til processen, samt de kommentarer der kom fra gruppen.

Begrundelser og diskussioner må medtages på h-drev eller usb, ligesom pensum er tilgængeligt. De to timers eksamen handler altså om at følge sin analyseplan og sammenskrive dette med det medbragte.

Det var en meget spændende oplevelse at se de studerende i denne situation. De knoklede, jublede og legede med teknikken, mens de arbejdede intenst med det faglige stof. Dem der var godt forberedte havde to lærerige timer. De uforberedte var stressede af tidspresset.

\section{Konklusion}

Brug af videoanalyse og litteratur i studieprocessen er et hjælpemiddel til at udvikle evnen til at analysere og sprogliggøre kropslige læreprocesser og dermed udvikle egne praktiske kompetencer, men samtidigt også mere specielle pædagogiske kompetencer og fagdidaktisk forståelse. Desuden giver det en mulighed for at udvikle en ny form for teoretisk-praktisk opgaveskrivning, hvor "en god nok opgave" benytter sig af muligheden for at kombinere kinæstetiske, visuelle og begrebslige kompetencer i dialog.

Dette er en arbejdsmåde som åbner for studie- og læreprocesser, hvor intentionen om en høj kobling af teori og praksis er karakteristisk for alle trin i forløbet.

At studiematerialet og en del af studieprocessen er aktivt tilgængelig på nettet udvider mulighed for at studere uafhængigt af sted og tid.

\section{Visioner perspektivering}

Den motiverende studieaktivitet, der hele vejen har været inspirerende at observere, vil være en spændende opgave for os i team "IFI-video" at få lejlighed til at dokumentere og beskrive i mere formelle rammer. Ved den her udvalgte beskrivelse i denne artikel har edb-medarbejder Otto Almind og undervisningsassistent Jørn Dam været en stor støtte. 